\title{
FAILURE ANALYSIS OF A POWER TRANSFORMER USING DISSOLVED GAS ANALYSIS - A CASE STUDY
}

\author{
Ankush Chander ${ }^{1}$ Nishant $^{2}$ \\ ${ }^{1}$ M. Tech Scholar, EEE Department Arni University Indora Himachal Pradesh, India \\ ${ }^{2}$ Assistant Professor, EEE Department, Arni University Indora Himachal Pradesh, India
}

\begin{abstract}
Reliable and continued performance of power Transformer is the key to profitable generation and transmission of electric power. Failure of a large power transformer not only results in the loss of very expensive equipment, but it can cause significant guarantied damage as well. Replacement of that transformer can take up to a year if the failure is not disastrous and can result in tremendous revenue losses and fines. A Power Transformer in operation is subjected to various stresses like thermal stress and electrical stress, resulting in liberation of gases from the hydrocarbon mineral oil which is used as insulant and coolant. Dissolved Gas Analysis is a technique used to assess incipient faults of the transformer by analyzing specific dissolved gas concentrations arising from the deterioration of the transformer. DGA is used not only as a diagnostic tool but also to track apparatus failure. In this case study the fault and defects that occurred in $400 \mathrm{kV} / 220 \mathrm{kV} / 132 \mathrm{kV} / 66 \mathrm{kV}$ Sub Station can be found by DGA.
\end{abstract}

Keywords: Power Transformer, Dissolved Gas Analysis,

\section{INTRODUCTION}

A power transformer is one of the most important and costly devices in electrical systems. Its importance is attributed directly to the continuity of power supply, since its loss through failure or defect means a supply stoppage. This is a large piece of equipment whose substitution is expensive and involves a lengthy process [11]. Power transformers, which are often the most valuable asset in a substation or plant, are indispensable components of high-voltage equipment for power generation plants, transmission systems and large industrial plants [15]. Unexpected failures cause major disturbances to operating systems, resulting in unscheduled outages and power delivery problems. Such failures can be the result of poor maintenance, poor operation, poor protection, undetected faults, or even severe lightning or short circuits. Power transformer failure could result in huge economic loss and unplanned outage of the power system, which may affect a large number of industries and commercial customers also Transformer failure will result in great loss in electrical system. Hence, a well establish maintenance should be conducted [10]

\section{FAILURES ANALYSIS}

A typical power transformer has a life expectancy of more than 30 years. During this time it is obvious that such a device has several failures, thus needing maintenance to ensure that the expectancy is fulfilled. Because transformer failures are responsible for a very high amount of costs, some of the most important causes of failures in power transformers are shown in table
Table 2.1 Failure Mode of Transformer

\begin{tabular}{|l|l|l|l|l|}
\hline \multirow{2}{*}{ Description } & \multicolumn{3}{|l|}{ Failures } & \multicolumn{2}{l|}{ Duration } \\
\cline { 2 - 5 } & No & $\%$ & TTF & ATF \\
\hline Periodical Test & 48 & 12 & $80: 39: 00$ & $\begin{array}{l}1: 40: 4 \\
9\end{array}$ \\
\hline Services & 56 & 14 & $88: 16: 00$ & $\begin{array}{l}1: 34: 3 \\
4\end{array}$ \\
\hline $\begin{array}{l}\text { Protective } \\
\text { Operation }\end{array}$ & 206 & 50 & $\begin{array}{l}264: 22: 0 \\
0\end{array}$ & $\begin{array}{l}1: 17: 0 \\
0\end{array}$ \\
\hline $\begin{array}{l}\text { Insulation } \\
\text { Problems }\end{array}$ & 16 & 04 & $\begin{array}{l}107: 40: 0 \\
0\end{array}$ & $\begin{array}{l}6: 43: 4 \\
5\end{array}$ \\
\hline $\begin{array}{l}\text { Others } \\
\text { Total }\end{array}$ & 86 & 21 & $\begin{array}{l}113: 23: 0 \\
0\end{array}$ & $\begin{array}{l}1: 19: 0 \\
6\end{array}$ \\
\hline
\end{tabular}

Results of Table 2.1 show that protective operation is the highest failure mode, but average times of the fault is the lowest, due to their causes are temporary and are removed after a little time. Further, in Fig.1.1, the percentage of any type of failures is shown. 


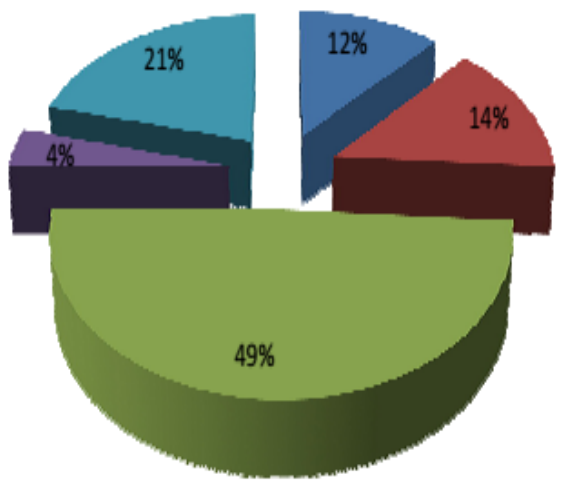

n Periodical Test

UServices

- Protective

Operation

Fig 2.1 The persentage of Failures

In other hand insulation problems are not too much but they have the highest average time of faults. The 5th group is consists of development interruption, bushing faults, tap changer faults, operator failures, lightning, unknown operation errors and etc. The most number of faults of this group are related to Tap Changer failures The main causes of the Tap changers failures start from sparking and erosion of the Tap Changer contacts. Moving parts malfunctioning can also lead to a failure. Eroded contacts produce sparking and sticking. In off -load Tap Changers long period without operation, leads to a corrosion and sludge build up which causes jamming of the moving parts and consequently, a failure of the Tap Changer. Therefore maintenance and periodical test and services can be reduced this type of failures.

\section{DISSOLVED GAS ANALYSIS}

Gases are formed in oil in the transformer due to natural aging and at much greater rate as a result of faults and incipient faults [1] [12]. The type and severity of a fault may often be inferred from the composition of the gases and the rate at which they are formed. In the case of an incipient fault, the gases formed remain partly dissolved in the oil and only in special cases will free gases be formed. Periodical sampling of oil from transformer and analysis of the dissolved gases assist in the detection of faults at an early stage of development and may enable serious future damage to transformer to be prevented [2] [9].

The gases involved are hydrogen, some hydrocarbons, carbon oxides and atmospheric gases. Some of each of these gases will be formed during normal operation and these amounts are classified as norm [3]. Fault conditions produce gases in higher quantity and in different proportions which vary from the norm, the type and energy of the fault altering the carbon to hydrogen ratio of oil molecules in specifically related ways and producing variation in the carbon oxide ratios when solid insulation is involved [8].
DGA was the first most effective diagnostic test, which was applied to transformers in service for condition monitoring [10]. Gases dissolved in oil are analyzed by gas Chromatography. The technique helps in detecting incipient faults developing in transformers. DGA is supplemented by other tests to confirm diagnosis [4]. Partial lists of fault gases that can be found within a unit are shown in the following three groups:

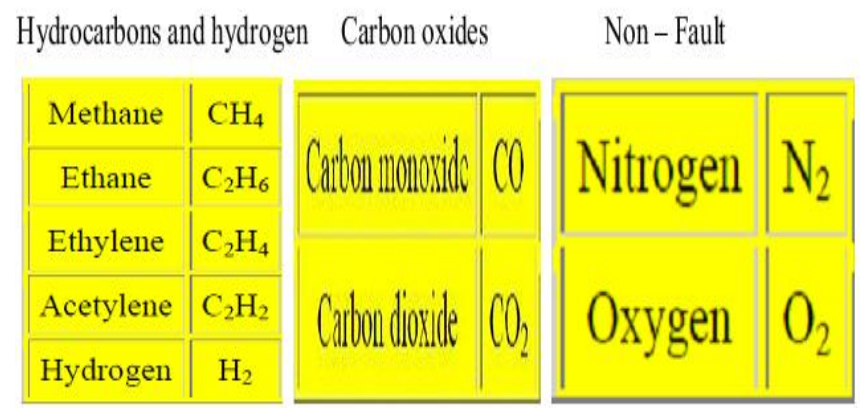

Fig 3.1: Gases Presented in Transformer Oil

The major (minor) fault gases can be categorized as follows in Table 3.1 and Interpretation of rise in gas concentration in Table 3.2 by the type of material that is involved and the type of fault present [5]: In this table characterization of various fault gases has been done and the major/minor faults occurring due to presence of gases have been shown [18]. If hydrogen traces found in oil then it resembles corona [14]

Table 3.1 Major/minor fault gases characterization

\begin{tabular}{|c|c|}
\hline \multicolumn{2}{|l|}{ Corona } \\
\hline Oil & $\mathrm{H}_{2}$ \\
\hline Cellulose & $\mathrm{H}_{2}, \mathrm{CO}, \mathrm{CO}_{2}$ \\
\hline \multicolumn{2}{|l|}{ Pyrolysis } \\
\hline \multicolumn{2}{|l|}{ Oil } \\
\hline Low temperature & $\mathrm{CH}_{4}, \mathrm{C}_{2} \mathrm{H}_{6}$ \\
\hline High temperature & $\mathrm{C}_{2} \mathrm{H}_{4}, \mathrm{H}_{2}\left(\mathrm{CH}_{4}, \mathrm{C}_{2} \mathrm{H}_{6}\right)$ \\
\hline \multicolumn{2}{|l|}{ Cellulose } \\
\hline Low temperature & $\mathrm{CO}_{2}(\mathrm{CO})$ \\
\hline High temperature & $\mathrm{CO}\left(\mathrm{CO}_{2}\right.$ \\
\hline Arcing & $\begin{array}{llll}\mathbf{H}_{2}, & \mathbf{C}_{2} & \mathbf{H}_{2}, & \left(\mathrm{CH}_{4},\right. \\
\mathrm{C}_{2} \mathbf{H}_{6}, & \mathbf{C}_{2} \mathbf{H}_{4}\end{array}$ \\
\hline
\end{tabular}

Table 3.2 Interpretation of rise in gas concentration:

\begin{tabular}{|ll|l|}
\hline $\begin{array}{l}\text { Rise in Gas } \\
\text { Concentration }\end{array}$ & Interpretation \\
\hline $\begin{array}{l}\text { Nil or not } \\
\text { appreciable }\end{array}$ & Normal Aging \\
\hline
\end{tabular}




\begin{tabular}{|l|l|}
\hline $\mathrm{H}_{2}$ & Corona, Partial Discharge \\
\hline $\mathrm{CH}_{4} \& \mathrm{C}_{2} \mathrm{H}_{6}$ & $\begin{array}{l}\text { Thermal fault of low } \\
\text { temperature upto 300® C }\end{array}$ \\
\hline $\mathrm{C}_{2} \mathrm{H}_{4} \quad$ With or & $\begin{array}{l}\text { Thermal fault of 300® } \mathrm{C} \text { to } \\
\text { Without } \mathrm{CH}_{4}, \mathrm{C}_{2} \mathrm{H}_{6},\end{array}$ \\
$\mathrm{H}_{2}$ & \\
\hline $\mathrm{C}_{2} \mathrm{H}_{2} \quad$ with $\mathrm{C}$ or above & \\
$\begin{array}{l}\text { Without } \\
\text { and } \mathrm{H}_{2} \quad \mathrm{C}_{2} \mathrm{H}_{4}\end{array}$ & Arc or Flashover \\
\hline
\end{tabular}

The main drawbacks [6] of this conventional method are unable to predict the fault of a particular transformer owing to the lack of expert knowledge in them.

\section{CASE STUDY DISSOLVED GAS ANALYSIS: $400 \mathrm{KV} / 220 \mathrm{KV} / 132 \mathrm{KV} / 66 \mathrm{KV} \mathrm{S} / \mathrm{S}$}

The case study include on the measurement of gas content in transformer oil using Dissolved Gas Analysis. The case study carried out $400 \mathrm{KV}$ Power Transformer, the rating of power transformer is given bellow:

The details of the transformer are as under: -

a. Rating: $12.5 / 16 \mathrm{MVA}, 66 / 11 \mathrm{kV}$

b. Sr.no. 2800061017

c. Make: NGEF

d. Date of Commissioning: 17-07-2003

e. Date of last dehydration of Oil: 2003

The DGA testing results for the above mentioned Power Transformer are shown in table5.1 given bellow

Table 4.1 DGA Testing Result

\begin{tabular}{|l|l|l|l|l|l|}
\hline $\begin{array}{l}\text { S. } \\
\text { N }\end{array}$ & Gas & $\begin{array}{l}\text { Quantity } \\
\text { detected in } \\
\text { ppm } \\
\text { Dated:10-10- } \\
\mathbf{2 0 0 7}\end{array}$ & $\begin{array}{l}\text { Dated: } \\
\mathbf{1 0 - 1 0 -} \\
\mathbf{2 0 0 9}\end{array}$ & $\begin{array}{l}\text { Dated: } \\
\mathbf{0 8 - 1 0 -} \\
\mathbf{2 0 1 1}\end{array}$ & $\begin{array}{l}\text { Date } \\
\text { d: } \\
\mathbf{3 0 -} \\
\mathbf{0 7 -} \\
\mathbf{2 0 1 3}\end{array}$ \\
\hline 1 & $\begin{array}{l}\text { Methan } \\
\text { e }\end{array}$ & 65 & 12 & 14 & 14 \\
\hline 2 & Ethane & 17 & 10 & 11 & 11 \\
\hline 3 & $\begin{array}{l}\text { Ethylen } \\
\text { e }\end{array}$ & 50 & 20 & 18 & 18 \\
\hline 4 & $\begin{array}{l}\text { Acetyle } \\
\text { ne }\end{array}$ & ND & ND & ND & ND \\
\hline 5 & $\begin{array}{l}\text { Carbon } \\
\text { dioxide }\end{array}$ & 350 & 765 & 770 & 770 \\
\hline 6 & $\begin{array}{l}\text { Hydrog } \\
\text { en }\end{array}$ & 25 & ND & ND & ND \\
\hline 7 & $\begin{array}{l}\text { TGC, } \\
\text { per } 100 \\
\text { ml } \\
\text { of oil. }\end{array}$ & $12.15 \mathrm{ml}$ & $\begin{array}{l}11.85 \\
\text { ml }\end{array}$ & $\begin{array}{l}11.90 \\
\text { ml }\end{array}$ & $\begin{array}{l}11.90 \\
\text { ml }\end{array}$ \\
\hline
\end{tabular}

Methane trends shows events of sparking and Ethane, carbon dioxide content is showing local \& severe overheating respectively. However, other gases found within permissible limits. Periodic testing and regular DGA is recommended for the Power Transformer, so that proper monitoring can be done to enhance the life of the Power Transformer. Further, for the 4 years the DGA Trend for the transformer is plotted in the graph shown in Fig 4.1

\section{DGA Transformer (HR)}

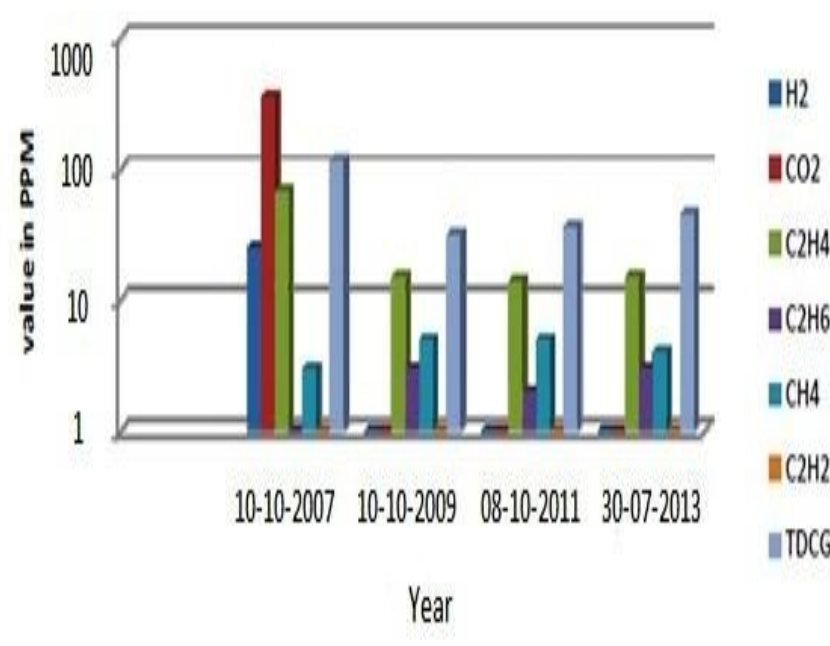

Fig 4.1 Yearly Graph Plot for DGA Result

Oil condition of the transformer is analyzed on the basis of DGA results. It is also seen that by dehydration of oil its BDV increases as well as the traces of various key gases also.

\section{CONCLUSIONS}

Dissolved Gas Analysis gives a good basis for a monitoring system as it can give a general picture of transformer health. Other parameters can be correlated with DGA to provide the user with detailed information about the condition of a transformer. From this work, the critical components can be carefully maintained. The known causes of failure can help to improve the equipment reliability. In this paper test results of DGA has been discussed and investigated and an attempt is made to find out the cause of fault and its preventive action. It has been found that proper and scheduled monitoring leads to enhanced life of Power Transformer and techniques like dehydration plays an important role in boosting up the condition of Transformer Oil as well the transformer life. However, still some advanced condition monitoring techniques like Partial discharge measurement, Spectrophotometer and SFRA etc. are not yet adaptive by the utilities and thus awareness and training on these issues is required for the betterment of the system 


\section{REFERENCES}

[1]. M. Wang, A.J. Vandermaar, and K.D. Srivastava, "Review of condition assessment of power transformers in service," Electrical Insulation Magazine, IEEE vol.18, pp. 12 - 25, Nov.-Dec. 2002

[2]. IEEE guide for the interpretation of gases generated in oilimmersed transformers, IEEE Standard C57.104-1991, July 1992.

[3]. S.D. Myers, J.J. Kelly, and R.H. Parrish, A Guide To Transformer Maintenance. United Stated of America: S.D. Myers Inc, 1981, p. 323

[4]. M. Arshad, S.M. Islam, and A. Khalig, "Power transformer critical diagnostics for reliability and life extension," Electrical and Computer Engineering, IEEE vol. 2, pp.625-628, May 2004.

[5]. R.A. Jongen, P.H.F. Morshuis, J.J. Smit, A.L.J. Janssen, and E.Gulski, "Failure data of power transformers as input for statistical failure analysis," presented at the 15th Int. Conf. High Voltage Engineering, Slovenia, 2007.

[6]. Statistical and Neural Network Analysis of Dissolved gases in power Transformers. K F Thang, R K aggarwal, D G ESP,A J McGrail, Dielectric Materials, Measurement and Applications ,Conference Publication No.473,IEE2000

[7]. CIGRE. Life management techniques for power transformers. Technical Brochure 227. Paris June 2003

[8]. Indian standard method of Evaluating of gases in oil filled Electrical Equipments. IS: 10593 - 1983.

[9]. IEEE Guide for the Interpretation of Gases Generated in Oil Immersed Transformers, ANSI/IEEE Standard C57. 1 041991.

[10]. Sanchez and Lav, Artificial Neural Network Newyork, USA: IEEE press, 1992.

[11]. L.Haykin, Neural Networks: A comprehensive Foundation. Montreal, Canada: Macmillan College Publishing Company Inc., 1994

[12]. Wang, M., Vandermaar, A.J., Srivastava, K.D. Review of condition assessment of power transformers in service. Electrical Insulation Magazine, IEEE Nov.-Dec. 2002 18(6): p. $12-25$

[13]. A. De Pablo, A.M., New guidelines for furans analysis as well as dissolved gas analysis in oil-filled transformers, in the International Council on Large Electric Systems (CIGRÉ), . 1996: Paris, France

[14]. E. Gockenbach, H.B., Diagnostic methods for transformers on-site, in Proc. Int. Symp. Elec. Insul. Matls., 1998: Toyohashi, Japan. p. 2 36.

[15]. Kachler, A.J., Diagnostic and monitoring technology for large power transformers, in CIGRé SC 12, Sydney Colloquium, . 1997: Sydney, Australia

[16]. R.J. Schwabe, et.al., On-line diagnostics of oil paper insulated instrument transformers, in theInternational Council on Large Electric Systems (CIGRé), . 2000: Paris, France

[17]. KIRTLEY, J.L., Jr., HAGMAN, Wayne H., et.al, Monitoring the health of power transformers. Computer Applications in Power, IEEE Jan. 1996 9(1): p. 18-23.
[18]. A. Mollmann, B.P., New guidelines for interpretation of dissolved gas analysis in oil filled transformers. Electra, 1999(186): p. 30 51. 